\title{
RETIREMENT BENEFIT IN MALAYSIA: UNDERSTANDING THE LEGAL FRAMEWORK AND ITS CHALLENGES TO THE MIGRANT WORKERS
}

\author{
Noor Shuhadawati Binti Mohamad Amin* \\ Ashgar Ali Ali Mohamed** \\ Areej Torla***
}

\begin{abstract}
The retirement benefits scheme is one of the social security protections accorded to employees around the world. In Malaysia, the retirement benefits scheme is in the form of the contribution made by both employer and employee at a specified rate based on the employee's monthly wages and such contribution will be credited into the employee's fund. An employee is allowed to withdraw money from the fund when he or she reaches retirement age. The doctrinal study found that the retirement benefits scheme in Malaysia differs greatly between the local employees and migrant workers. Although migrant workers are allowed to contribute to the retirement benefits scheme known as Employees Provident Fund, their contribution is voluntary, and not done compulsorily. The contribution of the employer is capped at only RM5 per month, which is very low. It is exacerbated by the fact that the contribution in the fund is not transferable as the Employees Provident Fund Act does not provide any provision to transfer the retirement benefit to another scheme in another country. It is hoped that these challenges faced by migrant workers will be given due consideration by the government to allow the migrant workers to have adequate social security protection by reforming the current retirement benefit statute or
\end{abstract}

* Assistant Professor, Civil Law Department, Ahmad Ibrahim Kulliyyah of Laws, International Islamic University Malaysia. Email: shuhadaamin@iium.edu.my.

** Professor, Civil Law Department, Ahmad Ibrahim Kulliyyah of Laws, International Islamic University Malaysia. Email: ashgar@iium.edu.my.

*** Assistant Professor, Civil Law Department, Ahmad Ibrahim Kulliyyah of Laws, International Islamic University Malaysia. Email: areej@iium.edu.my. 
introducing a new retirement benefit statute that only protects the migrant workers.

Keywords: $\quad$ Retirement benefit scheme, employee, migrant workers, challenges, law.

\title{
FAEDAH PERSARAAN DI MALAYSIA: MEMAHAMI KERANGKA UNDANG-UNDANG DAN CABARANNYA TERHADAP PEKERJA ASING
}

\begin{abstract}
ABSTRAK
Skim faedah persaraan merupakan salah satu perlindungan kebajikan sosial yang diberikan kepada pekerja di seluruh dunia. Di Malaysia, skim faedah persaraan adalah dalam bentuk sumbangan yang dibuat oleh kedua-dua majikan dan pekerja pada suatu kadar yang telah ditetapkan berdasarkan gaji bulanan pekerja, dan sumbangan tersebut akan dikreditkan ke dalam dana pekerja. Pekerja dibenarkan untuk mengeluarkan wang dari dana tersebut apabila pekerja itu mencapai umur persaraan. Kajian ini yang dilakukan secara doktrinal mendapati skim faedah persaraan di Malaysia sangat berbeza di antara pekerja tempatan dan pekerja asing. Walaupun pekerja asing dibenarkan untuk menyumbang kepada skim faedah persaraan yang dikenali sebagai Kumpulan Wang Simpanan Pekerja, sumbangan mereka adalah secara sukarela, bukan secara wajib. Sumbangan majikan adalah ditutup pada hanya RM5 setiap bulan, yang sangat rendah. Ianya ditambah dengan fakta bahawa sumbangan di dalam dana tersebut tidak boleh dipindah kerana Akta Kumpulan Wang Simpanan Pekerja tidak menyediakan apaapa peruntukan bagi tujuan pemindahan faedah persaraan ke skim yang lain di negara lain. Diharap segala cabaran yang dihadapi oleh pekerja asing akan diberi pertimbangan sewajarnya oleh kerajaan untuk membenarkan pekerja-pekerja asing ini diberikan perlindungan kebajikan sosial yang mencukupi dengan melakukan reformasi terhadap undang-undang faedah persaraan atau memperkenalkan undang-undang faedah persaraan yang baru yang hanya melindungi pekerja-pekerja asing.
\end{abstract}

Kata kunci: Skim faedah persaraan, pekerja, pekerja asing, cabaran, undang-undang. 


\subsection{Introduction}

Old age is one of the contingencies enumerated in the International Labour Organisation (hereinafter referred to as ILO) Convention on social security. Old-age benefit, or widely known as the retirement benefit, is normally structured in the form of a provident fund that offers a savings mechanism for those who are currently working. Once these people retire or leave the country, they will receive a lump-sum payment. Provident fund is a compulsory collective-savings scheme that is publicly administered. It is financed by the contributions made by the employees and/or the employers and from the investment made using the fund.

Contributions made by the employee or made by the employer on behalf of an employee and a share of the fund's investment earnings are credited to the employee's account. When a member of the provident fund reaches retirement age, he or she is eligible to withdraw part or all of the balance from their account. Most provident funds allow their member to withdraw from his or her account before reaching the retirement age in prescribed circumstances including purchasing a home. ${ }^{1}$ This fund which is better known as the Employees Provident Fund (hereinafter referred to as EPF) does not only provide retirement savings, but also extends benefits for other purposes, namely education, housing, health care, and most recently, pilgrimage. These benefits are extended through a separate contribution at a rate determined by the EPF Board ${ }^{2}$ (hereinafter referred to as the Board)

1 ILO, Strengthening Social Protection for ASEAN Migrant Workers through Social Security Agreements, ILO Publication, Geneva, 2007 at 5.

2 In S 3 of EPFA, "Board" refers to For the purposes of managing the Fund and for carrying into effect the purposes of this Act, there is hereby established a body corporate by the name of "Employees Provident Fund Board" with perpetual succession and a common seal, and which may sue and be sued in its corporate name and, subject to and for the purposes of this Act, may enter into contracts and may acquire, purchase, take, hold, and enjoy movable and immovable property of every description and may convey, assign, surrender, yield up, charge, mortgage, demise, reassign, transfer, or otherwise dispose of, or deal with any movable or immovable property, or any interest therein vested in the Board upon such terms as it deems fit. 
established under the Employees' Provident Fund Act 1991 (hereinafter referred to as EPFA). ${ }^{3}$

While Article 8 of the Federal Constitution ${ }^{4}$ guarantees the equality of treatment to everyone, there seems to be an inequality in the retirement scheme between the local workers and the migrant workers. The concern arises because Malaysia is still providing low protection to the migrant workers; they are only protected minimally in terms of old-age benefits. Under EPFA, ${ }^{5}$ the contribution of the employer for the migrant workers is capped at only RM5 per month although the migrant workers' contribution is based on percentages. This situation is further exacerbated by the fact that the scheme is not mandatory for migrant workers. ${ }^{6}$ The small contribution from the employer and the optional contribution by the migrant worker may cause financial issues to the migrant workers during their retirement. EPF does not allow the transferring of the social security right, particularly retirement benefit, to another scheme in another country. EPFA only permits the nonnational employee to withdraw all the money standing to the employee's credit in the EPF fund should the employee has no intention to return to Malaysia. The portability of social security

3 The contribution rate for savings toward other objectives besides retirement is currently capped at $6.9 \%$. They include education, housing, health care, and the recent hajj. The contribution rates for people aged from 60 until 75 were regulated at half the normal rates: either $6 \%, 6.5 \%$, or 5.5\% respectively. See Holzmann, R, "Old-Age Financial Protection in Malaysia: Challenges and Options," IZA Policy Paper No. 96, Institute of Study of Labour, 2015.

4 Art. 8 (1) of the Federal Constitution reads: All persons are equal before the law and entitled to equal protection of the law.

5 The employer's contribution for migrant worker was legislated through the amendment in 2007; the Employees Provident Fund (Amendment) Act 2007 Act A1300. The amendment effectively cuts the employer's EPF contribution for migrant workers to a flat rate of RM5 monthly compared to $12 \%$ of salary before. See "An unfair pay cut through the EPF Bill," The Sun Daily, 17 April, 2007, http://www.thesundaily.my/node/170642 viewed on 1 October 2018.

6 Following the amendment in August 1998 in the Employees Provident Fund (Amendment of First Schedule and Third Schedule) Order 1998 P.U. (A) 290/1998, Employees Provident Fund (Amendment of First Schedule and Third Schedule) (No. 2) Order 1998 P.U. (A) 414/1998. These amendments restrict the rate of contribution of the employers to the migrant worker to be capped at RM5 per month. 
benefits in Malaysia is claimed to be caused by the lack of proper coordination between countries in terms of the rights acquired or in the course of acquisition.

The objectives of this paper are first to evaluate the retirement benefit's legal framework for private-sector employees in Malaysia by looking at the structure of the scheme via coverage of the EPFA and the contribution made by both employer and employee to the EPF fund to the local employees in general. This paper also seeks to analyse legal provisions in Malaysia that apply to migrant workers at present. Subsequently, the challenges faced by the migrant workers concerning the limitation of the EPFA are discussed. Lastly, reformation of the laws and policies related to the old-age retirement scheme is proposed.

\subsection{Development of Retirement Benefit in Malaysia}

Malaysia's provident fund is said to be the oldest provident fund in the world and it is regarded as one of the most successful. ${ }^{7}$ EPF came into force in 1951 following the widespread establishment of few provident funds for the employees of the plantation and mining companies. EPF Ordinance was introduced in 1951 by the Federal Labour Department in response to the need for the retirement savings benefits to be streamlined for every employee to enjoy financial security upon retirement. ${ }^{8}$ At present, EPF provides retirement benefits to the private sector employees and the non-pensionable public sector employees. As for the public sector employees, their social security benefits are governed by the Pension Act 1980. The statute provides for the administration of pensions, gratuities, and other benefits for the civil servants and their dependents. At this juncture, it is worthy to note that

7 The EPFA 1991 was enacted to amend and re-enact the Employees Provident Fund Ordinance 1951 regarding the provident fund for "persons employed in certain occupations and for matters incidental thereto." See also R. Thillainathan, "The Employees Provident Fund of Malaysia: Asset Allocation, Investment Strategy and Governance Issues Revisited," Pension Fund Management Workshop, Kuala Lumpur, 14 - 15 August, 2000.

8 Tan Sri Sallehuddin Mohamed, "The Employees Provident Fund \& You," $\mathrm{EPF}$

Forum,

(n.d).

http://portal.mim.org.my/resources/MMR/9509/950906.Htm viewed on 1 June 2015. 
although EPFA is offered to the migrant workers as they are part of the private sector employees, the protection is not made mandatory with various limitations stated therein.

In 1968, EPF introduced its first partial-withdrawal scheme where up to one-third of the accumulated savings of its members can be withdrawn. From thereon, EPF has made several changes to preretirement withdrawal arrangements. ${ }^{9}$ The framework of the fund is frequently amended and developed. ${ }^{10}$ The latest example is the inclusion of the provision in EPFA that allows the withdrawal of the fund to perform hajj or pilgrimage for its Muslim members. This is so, provided that the member had received a letter of offer to perform the hajj from the Pilgrim Fund Board (Lembaga Tabung Haji). ${ }^{11}$

EPF has deployed many strategies and structural reforms since its inception including investments in all major markets in various asset classes. The decision-making process is split into two separate entities, the Board and a panel specifically entrusted with the investment

9 Saidatulakmal Mohamad, "Social Protection in Malaysia," Arab Forum on Social Policy, Beirut, 28 - 29 October 2009. at 2.

10 List of Amendments to EPFA are as follows: Employees Provident Fund (Amendment of Third Schedule) Order 1992 P.U. (A) 551/1992, Employees Provident Fund (Amendment) Act 1995 Act A914, Employees Provident Fund (Amendment of Third Schedule) Order 1996 P.U. (A) 30/1996, Employees Provident Fund (Amendment) Act 1996 Act A958, Employees Provident Fund (Amendment of First Schedule and Third Schedule) Order 1998 P.U. (A) 290/1998, Employees Provident Fund (Amendment of First Schedule and Third Schedule) (No. 2) Order 1998 P.U. (A) 414/1998, Employees Provident Fund (Amendment) Act 2000 Act A1080, Employees Provident Fund

(Amendment of Third until Schedule) Order 2001 P.U. (A) 135/2001, Employees Provident Fund \& (Amendment) Act 2001 Act A1123, Employees Provident Fund (Amendment of Third Schedule) Order 2002 P.U. (A) 120/2002, Employees Provident Fund (Amendment) Act 2003 Act A1190, Employees Provident Fund (Amendment of Third until Schedule) Order 2003 P.U. (A) 171/2003, Employees Provident Fund (Amendment of Fifth and Sixth Schedule) Order 2003 P.U. (A) 227/2003 and Employees Provident Fund (Amendment of Third Schedule) Order 2004 P.U. (A) 178/2004.

11 See S 54 (6) (ga) of EPFA. It allows eligible Muslim EPF members to withdraw up to RM3,000 from their Account 2 to finance the cost of their Hajj partly. Such withdrawal was made effective from 1 January 2013. 
decision also known as the Investment Panel. For the purpose of transparency, the EPF would voluntarily disclose its investment position and performance quarterly, instead of on an annual basis as required. ${ }^{12}$

\subsection{Structure of Retirement Benefit in Malaysia: An Overview}

Old-age benefit, or widely known as the retirement benefit, is normally structured in the form of a provident fund that offers a savings mechanism for those who are currently working. Once these people retire or leave the country, they will receive a lump-sum payment. Provident fund is a compulsory collective-savings scheme that is publicly administered. It is financed by the contributions made by the employees and/or the employers and from the investment made using the fund. The coverage and contribution mentioned below are meant specifically to the local workers while migrant workers are governed by a separate provision of the EPFA.

\subsection{Coverage}

In general, EPF provides a savings scheme structured to accommodate the needs of private-sector employees for retirement purposes. Under the Act, the retirement benefit is defined as "any payment paid to an employee upon retirement, either compulsory or optional or on medical grounds, as stated under the contract of service of the employee." 13 This clearly illustrates that the retirement benefit can be made either compulsory or voluntary. Saving in the provident fund is made mandatory for private-sector workers including the migrant workers who hold permanent residency in Malaysia. It is also compulsory for the non-pensionable public sector workers to contribute to the fund. Nonetheless, several categories of people are excluded from the definition of "employee" as specified in the First Schedule of the Act. They include domestic servants; out-workers; detainees in any prison, detention school or place, mental hospital, rehabilitation centre as

12 The World Bank, "Case Study on the Employees Provident Fund of Malaysia," November 6, 2018, https://www.worldbank.org/en/country/malaysia/publication/case-studyon-the-employees-provident-fund-of-malaysia viewed on 22 July 2021.

13 See S 2 of EPFA. 
defined in the Drug Dependants (Treatment and Rehabilitation) $\mathrm{Act}^{14}$ or leper settlement; person holding temporary pass to remain in Malaysia issued under immigration law who has not given one month's notice to the Board and the employer of his intention to be a member; a person who is participating in a provident fund or other similar scheme administered and established outside Malaysia while being employed within the country but his or her country of domicile is outside Malaysia; a member of the administration as specified in Article 160 of Federal Constitution; ${ }^{15}$ and lastly person attaining the age of 75 years.

Nevertheless, the exclusion of these categories of people from contributing to the fund is not absolute. Contribution to the scheme can also be made voluntarily by several categories of people listed in Section 43 (8) of the Act by giving notice in a prescribed manner and selecting to contribute monthly following the prescribed rate. They are the self-employed person; a pensionable employee; a person who is not included within the definition of an employer or an employee of this Act; or a person as mentioned in (c) above who had consented to make contributions to the fund.

From the above, there is no specific provision prohibiting migrant workers from being covered in the scheme. It should be noted that migrant workers are dealt with in a specific part of the EPFA following the amendment made in the Act in 2001.

141983 [Act 283]. Rehabilitation Centre under this Act refers to the centre established for the residence, treatment, and rehabilitation of drug dependants ordered or admitted to reside therein under this Act.

15 Art 160 of Federal Constitution defines Member of the Administration in relation to the Federation as "a person holding office as Minister, Deputy Minister, Parliamentary Secretary, or Political Secretary and, in relation to a State, a person holding a corresponding office in the State or holding office as member (other than an official member) of the Executive Council." 


\subsection{Contributions}

Contributions to the fund are only made by the employer and employee ${ }^{16}$ Section 45 (1) of the Act states that the employer shall be liable to pay the contributions based on the employee's monthly wages by himself. The section also depicts that the contribution on behalf of the employee refers to the contribution from the employee's monthly wages. ${ }^{17}$ An employer's failure to do so will make the employer liable to pay the contributions due within such a period prescribed by the Minister. The employer is also liable to pay a dividend that would have accrued on such contributions should all the contributions due had been paid by the employer diligently. The dividend payment must be done within the prescribed period at the rate determined by the Board. ${ }^{18}$ The employer cannot deduct or recover the employer's contributions from the employee's wages or remuneration. If an employer is found guilty of such an act, he will be liable for imprisonment for not more than six years or a fine not more than RM20,000 or both. ${ }^{19}$

EPF is a statutorily-mandated fund that consists of the contributions from the shares of both the employer and the employee based on the employee's monthly wage ${ }^{20}$ at a rate listed in the Third

16 It should be noted that there is an annual tax relief up to RM6,000 for the contributions made by employees to the EPF scheme and life insurance. See S 49 of Income Tax Act 1967 (Act 53).

17 See $\mathrm{S} 45$ (1) of EPFA.

18 See S 45 (3) of the Act. In S 45 (4), failure in doing so, he will be subject to imprisonment for a term not more than three years or a fine not more than RM10,000 or to both. In relation to this, the employer is also liable to pay interest for the contributions in arrears. Section 49 (1) of the Act reads Where the amount of the monthly contributions or part of any monthly contributions which an employer is liable to pay under Section 45 is not paid within such period as may be prescribed, the employer shall be liable, in addition to the dividend to be paid under Subsection 45(3), to pay interest to be credited to the Fund on such amount at such rate (being a rate per annum) as declared by the Board from time to time in respect of each month or part of a month after expiration of such period during which such amount remains unpaid.

19 See $\mathrm{S} 47$ of EPFA.

20 In S 2 of EPFA, "wages" means all remuneration in money due to an employee under his contract of service or apprenticeship whether agreed to be paid monthly, weekly, daily, or otherwise, and includes any bonus, commission, or allowance payable by the employer to the employee 
Schedule of EPFA. This is evident from Section 43 (1) of EPFA that makes it mandatory for each employer and employee to pay monthly contributions on the wages for the month at the prescribed rate. ${ }^{21}$ An employer who fails to do so will be guilty of an offence and upon conviction, is liable to up to three years imprisonment or fine not exceeding RM10,000, or both. ${ }^{22}$

Conversely, if the employer paid for both employer and employee's contributions on behalf of the employee, the sum paid by the employer for the employee's EPF contributions was a debt owed by the employee to the employer. This is because an otherwise consideration would be an unjust enrichment to the employee. ${ }^{23}$ If the employer or employee chooses to contribute more than the prescribed rate, he can do so by giving notice to the Board. ${ }^{24}$

whether such bonus, commission, or allowance is payable under his contract of service, apprenticeship, or otherwise, but does not include

(a) service charge;

(b) overtime payment;

(c) gratuity;

(d) retirement benefit;

(e) retrenchment, lay-off, or termination benefits;

(f) any travelling allowance or the value of any travelling concession; or

(g) any other remuneration or payment as may be exempted by the Minister.

21 See S 43 (1) of EPFA. The deduction from the employee's salary for the purpose of contribution to EPF scheme is in line with S 24 of EA which makes it lawful for employers to make deductions authorised by any other written law. See S 24 (2) (d) of EA.

22 See S 43 (2) of EPFA. See the case of PP v Roche Sdn Bhd [2014] 6 CLJ 371. In this case, the court held that employer's failure to contribute in the EPF fund for employee's wages does not constitute an offence under S 43 (2) of EPFA as the employee had retired and was no longer an employee of the respondent employed under a contract of service. He was appointed as a Human Resource consultant under a contract for service and received a consultancy fee. The court also found that although the respondent did not pay the employer's EPF contribution, the respondent nevertheless had paid the $19 \%$ employer's contribution directly to the employee through his compensation package.

23 See Dato' Joseph Lai Khee Sin \& Ors v Fong Wai Heng [2015] 7 CLJ 785.

24 See S 43 (3) and (4) of EPFA. 
As shown in the Third Schedule, the rate is determined based on age, salary, and nationality of a member. Part A of the Third Schedule states that for those who are below the age of 60 years who earn up to RM5,000 monthly, the employer's rate of contribution is $13 \%$ based on the employee's monthly wage. Meanwhile, the employee's rate of contribution is capped at $11 \%$. As for those who earn RM5,000 and above, the employer's rate of contribution is $12 \%$ based on the employee's monthly wage and the employee's rate of contribution remains at $11 \%$.

Part $\mathrm{C}$ of the said Schedule states that for those attaining the age of 60 years who earned up to RM5,000 monthly, the employer's rate of contribution is $6.5 \%$ based on the employee's monthly wage, and the employee's rate of contribution is capped at $5.5 \%$. As for those who earned RM5,000 and above, the employer's rate of contribution is $6 \%$ based on the employee's monthly wage and the employee's rate of contribution remains at 5.5\%. Part A and C of the Schedule apply to the categories of people listed below:

(a) National employees;

(b) Non-national employees holding permanent resident status; and

(c) Non-national employees who had chosen to contribute prior to 1 August 1998.

In the event when the monthly wages exceed RM20,000, the rate of contribution by the employee shall be $11 \%$ and the rate of contribution by the employer shall be $12 \%$ from the wages for the month.

From the above, it is noted that national and non-national employees are in different categories. For non-national employees, they can be further be divided into two; namely, those holding permanent resident status and those who are not but choose to contribute before 1st August 1998. However, with the amendment to EPFA which was effective starting 1st August 1998, Part B and D of the Third Schedule were amended to cater for the expatriates and migrant workers who wish to contribute to the fund. ${ }^{25}$ These Parts apply to the non-national employees who have elected to contribute:

25 See Employees' Provident Fund (Amendment) Act 1997 (Act A981). 
(a) On or after 1 August 1998;

(c) Under Paragraph 3 of the First Schedule ${ }^{26}$ on or after 1 August 1998; and

(d) Under Paragraph 6 of the First Schedule ${ }^{27}$ on or after 1 August 2001.

This part is specifically intended to cover migrant workers who are currently working in Malaysia. Cut-off dates were included to separate migrant workers before and after the amendment made to the Act governing these workers.

In Part B of the Third Schedule, for those below the age of 60 years, the employer's rate of contribution is RM5 and the employee's rate of contribution is capped at $11 \%$, regardless of the monthly wages. Meanwhile, under Part D of the said Schedule, for those attaining the age of 60 years, the employer's rate of contribution is maintained at RM5 and the employee's rate of contribution is capped at $5.5 \%$, regardless of the monthly wages.

Each member's contributions are separated into three dedicated accounts with each account having special withdrawal requirements. Currently, $70 \%$ of contributions are deposited into Account 1; members are not allowed to withdraw from this account until they reach the age of 55 years old. Upon reaching the age, the members can withdraw their funds in several manners: (i) as a single lump sum, (ii) part lump sum with a balance to be paid in periodical payments, or (iii) withdraw the dividend yearly, leaving the balance in the account. ${ }^{28}$

26 Para 3 of the First Schedule states that Domestic servants as defined aforesaid (other than those excepted under Paragraph (2)) who have not, in respect of any employment in which they are then engaged, given to the Board and their employers one month's notice in the prescribed form of their intention to be members of the Fund.

27 Para 6 of the First Schedule reads as follows Any person who is employed and whose country of domicile is outside Malaysia and who enters and remains temporarily under the authority of any pass issued under the provisions of any written law relating to immigration and who has not given to the Board and his employer one month's notice in the prescribed form of his intention to be a member of the Fund.

28 See S 55 (1) of EPFA and 55A of EPFA. However, the provision does not apply to the member of the Fund who is physically or mentally 
The remaining 30\% is allocated in Account II; withdrawals from this account are allowed to buy or build a house, for the payment of housing loans, and other purposes as stipulated in Section 54 (6) of the Act. The balance of this account and its compounded interest may be withdrawn at the age of 50 years.

Section 50 of EPFA states that the amount of any contributions paid by the employer on his own behalf and on behalf of the member, dividend on any amount standing to the credit of the member at the prescribed rate, and any other money paid on behalf of such member in accordance with this Act shall be credited to the member's account. ${ }^{29}$ Subsection 2A sets the maximum age for the contribution and dividend to be credited into the member's account. ${ }^{30}$

\subsection{Challenges of Retirement Benefit to the Migrant Workers in Malaysia}

Initially, in January 1998, the employers and migrant workers in this country were made mandatory to contribute to EPF at rates based on the monthly wages of the latter; $12 \%$ by the employer and $11 \%$ of monthly wages by the employees. ${ }^{31}$ This provision was later revoked in 2001 and new provisions on the position of migrant workers are envisaged in Part VIIA of EPFA. The revocation of the mandatory savings for migrant workers and expatriates is caused by the employers' onerous feeling because they have to contribute for these foreigners who are working temporarily in this country. Some

incapacitated from engaging in an employment, the member of the Fund is not a Malaysian citizen and is about to leave Malaysia with no intention of returning to Malaysia and for those who seeks to withdraw part of the saving for the contingencies stated in Section 54 (6) of EPFA.

29 See S 50 (2) of EPFA.

30 It reads as follows:

(a) no amount of contributions or money may be credited into the account of a member of the Fund after such member has attained the age of seventy-five years; and

(b) no dividend may be credited on any amount standing to the credit of a member of the Fund after such member has attained the age of seventy-five years.

31 Devadason, Evelyn Shymala and Chan, Wai Meng, Inflow of Foreign Labour into Malaysia: Conceptualizing Economic and Legal Issues, FEA Working Paper No. 2007-17, University Malaya, 2007 at 8. 
employers have resorted to hiring illegal migrant workers in their attempt to avoid having to contribute to the EPF scheme for their foreign workers. Apart from hiring illegal migrant workers, several reports have shown that the employers had reduced the wages for these migrant workers, subsequently reducing their part of contributions to the EPF scheme for their migrant workers. ${ }^{32}$ Although making the contribution non-mandatory may seem to resolve the issue of hiring illegal workers, the setback would be that documented migrant workers are now left with no old-age benefit.

\section{1 Migrant Worker's Optional Contribution and Employer's Low Contribution for Old-Age Benefit}

It is primarily important to note that the migrant worker is not obligated to contribute to the scheme because this is optional upon them. Further, even if they choose to contribute, the share of the employer will be capped at RM5 only. This is significantly different from the local employees where the share of the employer's contribution based on the employee's salary is $12 \%$ while the local employee's share is $11 \%$.

With the limitations imposed on the migrant workers, contribution to the scheme may not serve as a good retirement plan for them. As such, the migrant workers in this country choose to remit a portion of their earnings to their countries of origin to meet certain economic and financial obligations ${ }^{33}$ as well as for their retirement savings. Recently, the government is reportedly considering employing a mechanism to reduce the remittances by the migrant workers in Malaysia in a bid to curtail the outflow of the ringgit. The severe currency outflows ultimately affect the national economy.

Through the proposed mechanism which is set up in a manner similar to the EPF, the migrant workers' salaries would be deducted as remittances to the fund. The details for the payment of the percentage of the migrant workers' salary and the withdrawal from the proposed

32 Prema-Chandra Athukorala and Evelyn S. Devadason, "Foreign Labour in Malaysian Manufacturing: Trends, Patterns and Implications for Domestic Wages," Trade and Employment in Asia, edited by Nina Khor and Devashish Mitra, Routledge, 2013 at 251.

33 Asian Development Bank, Workers' Remittance Flows in Southeast Asia, Asian Development Bank, 2006 at 18. 
fund are still being studied before the proposed scheme can be implemented. Interestingly, this new scheme is currently developed by the Ministry of Home Affairs (hereinafter referred to as MOHA) although in general, the Ministry of Human Resource (hereinafter referred to as MOHR) is in charge of social security matters concerning the migrant workers. ${ }^{34}$

\subsection{Non-transferability of Social Security Rights Across Borders}

Under the current social security system, portability and transferability of social security benefits are almost non-existent, except in very limited situations as stated in a few statutes. EPF does not provide any provision to transfer the social security right - the retirement benefit to another scheme in another country. Under Section 54 (1) (e) of EPFA, the non-national member of the fund who is about to leave Malaysia with no intention of returning to Malaysia may withdraw all sums of money standing to his credit. On the contrary, Workmen Compensation Act 1952 (WCA) has a provision allowing for the transfer of the employment injury benefit of a workman to the beneficiaries in another Commonwealth country. This is evident in Section 42 of WCA which states that

Where an arrangement has been made between the Government of Malaysia and the Government of any part of the Commonwealth, whereby sums awarded under the law relating to workmen's compensation in Malaysia to beneficiaries resident or becoming resident in the territory administered by any such Government, and sums awarded under the law relating to workmen's compensation in any such territory to beneficiaries resident or becoming resident in Malaysia, may at the request of the authority by which the award is made be transferred to and administered by a competent authority in any such territory or by the Commissioner in Malaysia, as the case may be, money in the hands of the Commissioner shall be transferred, and money received by him shall be administered, in the manner prescribed.

Theoretically, although the portability of workmen's compensation is possible by virtue of the above provision, it should be

34 "EPF-like fund for foreigners?" Sin Chew Daily, 19 October 2015, http://www.mysinchew.com/node/111659 viewed on 13 November 2018. 
noted that the compensation is in the form of a lump sum payment. As such, the residency requirements are not required for the beneficiaries to access the benefits and for the transfer of the periods of the contribution of the migrant workers to another country. Currently, no specific bilateral or multilateral agreement is in force with any country for this purpose; most of the Memorandum of Understandings (hereinafter referred to as MOUs) and agreements entered into focused only on the general subject of labour migration. Malaysia had only signed the MOUs with Bangladesh, China, Sri Lanka, Thailand, Pakistan, Vietnam, and Indonesia for the purpose of regulating recruitment processes and procedures. ${ }^{35}$

Holzmann identified four regimes of social security protection of migrant workers. Under the first regime, migrant workers have access to the social security system in host countries. Both host countries and migrant workers' countries of origin have social security agreements that allow the migrant workers to bring benefits when they return to their countries of origin. ${ }^{36}$

Meanwhile, the second regime allows the migrants to have access to social security arrangements in the host country but with the absence of any social security agreement concluded between the host countries and migrants' countries of origin. Malaysia falls under this regime as at the moment, no agreement is concluded between Malaysia and other labour-sending countries although the migrant workers in this country are covered in the national social security legislation. ${ }^{37}$

Malaysia falls under the second category of the regime based on a few reasons. Firstly, the possibility of incompatibility of schemes that

35 ILO, "Bilateral agreements and regional cooperation," http://www.ilo.org/global/docs/WCMS_226300/lang--en/index.htm viewed on 15 June 2015.

36 Robert Holzmann, Johannes Koettl, and Taras Chernetsky, "Portability Regimes of Pension and Health Care Benefits for International Migrants: An Analysis of Issues and Good Practices," The Global Commission on International Migration, May 2005, Social Protection Discussion Paper Series, No. 0519, Social Protection Unit, Human Development Network, The World Bank at 7 - 8.

37 Gloria Pasadilla, "Portable Social Security for ASEAN Migrants," Asian Pathways, A Blog of the Asian Development Bank Institute, http://www.asiapathways-adbi.org/2012/02/portable-social-security-forasean-migrants/\#sthash.Zsiz4bNu.dpuf viewed on 20 July 2019. 
are available in the country of origin and the country of employment. Secondly, the national legislation of these countries is based on the principle of territoriality and nationality. ${ }^{38}$ Thirdly, the duration of the migrant workers' employment in this country is only up to five years. With such a short duration of time, it is hard for the relevant ministry to monitor the record of each migrant worker coming in and out of the country. Lastly, for the administration of the social security benefits, there must be a designated unit to handle the matter and this could impose a financial burden on the government.

\subsection{Other Challenges}

As stated above, Part VIIA applies to each non-national member of the fund who chooses to contribute on or after 1 August $1998 .{ }^{39}$ A migrant worker who is a member of the fund may withdraw all amount standing to his credit in several situations: when the member of the fund passed away, when the member of the fund is incapacitated either physically or mentally as in the course of employment, or when the member of the fund is about to leave the country with no intention of returning. ${ }^{40}$ Since the revocation of the mandatory savings for migrant workers took effect in 2001, the migrant workers who had contributed starting 1

38 There are several features of the national legislations impeding social security rights to the migrant workers. Firstly, is known as principle of territoriality. Under this principle, the scope of application of social security laws is restricted to the territory of the country in which it has been enacted. Apart from portraying the sovereignty of the state, this principle was also derived as a result of legal and administrative problems in enforcing compulsory legislation in another state which caused the migrant workers to either lose coverage, or granted limited coverage, or in the worst case, no coverage at all in the host country. Secondly, the principle of nationality is another feature of the national legislation which is affecting the rights of the migrant workers. Some countries enacted social security legislations in a way that discriminate the migrant workers by excluding them or in worse case, all non-nationals are excluded from the coverage or entitlement to the benefits.

39 See S 70A of EPFA that states as follows: "This Part shall apply to each member of the Fund who is not a Malaysian citizen who elects to contribute on or after 1 August 1998."

40 See S 70C of EPFA. This provision is similar to the provision concerning the national member of the fund as stated in S 54 (1) of EPFA. 
August 1998 until 1 August 2001 are entitled to the return of all the amount standing to their credit within the period. ${ }^{41}$

Further, a non-national does not have the same entitlement as the national member regarding the nomination. ${ }^{42}$ In Section 54 (1A) of the Act, for the purpose of Section 54 (1) (a), a member of the fund may make a nomination for the payment of credit upon his death. Notably, most provisions under the Act apply to the non-national members of the fund with exception of certain provisions.

Next, limitations for the non-national member of the fund include the non-payment of dividends to the migrant workers, lack of additional payment from EPF itself to the member of the fund in case of death or disablement, and the inclusion of insurance policy. ${ }^{43}$

In Section 70G of the Act, non-national employees shall cease to contribute on the last two months before the expiry of their work permit or before the expiry of the extension of their work permit. ${ }^{44}$ Currently, 247,379 migrant workers are registered with the EPF scheme, but as of December 2015, only 9,929 migrant workers are regarded as active members. ${ }^{45}$

Furthermore, no option is available for a migrant worker who wishes to withdraw the money standing to his or her credit, especially for the purpose of medical financing, ${ }^{46}$ before he leaves the country.

41 See $\mathrm{S} 70 \mathrm{~F}$ of the Act.

42 See $S 70 D$ of EPFA.

43 See S 70E of the Act. The provisions which are not applicable to the foreign member of the fund are as follows: S 29A of EPFA in relation to the national member of the fund who is allowed to make investment, S 54 (1) of the Act concerning the withdrawal of the fund and since S 70C of the Act also regulates the same for the foreigners. S 54A of the Act is regarding to the payment of dividend, S 58 is about the payment of additional amount in case of death and incapacitation of the member either physically or mentally, and finally S 58B is concerning the taking up of insurance policy which is not applicable to the non-national member of the fund.

44 See $\mathrm{S} 70 \mathrm{G}$ of the Act.

45 Norasyikin Che Puteh, "Collection of Data for Ph.D Thesis," Active members here refer to migrant workers who are making monthly contributions to the EPF fund, E-mail to Author, 6 January 2016.

46 Please refer to S 54 (6) (f) of EPFA which allows for the local worker to make withdrawal from the EPF scheme. 
Conversely, the local workers can enjoy withdrawal of money from the scheme even before reaching the retirement age.

\subsection{Reforming Retirement Benefit Legal Framework for Migrant Workers}

In terms of old-age benefits, reference should be made to the newly proposed EPF-like scheme by the MOHA. Additionally, the provisions stated in the EPFA need to be reviewed, particularly those relating to migrant workers.

\subsection{Introduction of a New Retirement Scheme Statute for Migrant Workers}

By introducing the new retirement scheme for migrant workers, the scheme should be made based on the percentage following the mechanism employed in the EPF scheme. To that end, the employer's share of contribution will no longer be capped at RM5 per month. Nonetheless, taking into account the salary and duration of employment of the migrant workers, a possibility exists for such percentage to not be similar to the one implemented in the EPF scheme.

Additionally, the scheme should also make such contribution mandatory to the migrant worker compared to the current scheme which is on a voluntary basis. The new EPF-like scheme should also uplift the limitations mentioned in EPFA by providing a reasonable dividend payment to them and allowing for nomination for the payment of credit in case of the death of the worker. Options for transferring the benefits should also be available in the new scheme so that the migrant workers who wish to return to their country of origin can enjoy the same benefit in a similar scheme when they begin to work in their home country.

\subsection{Reviewing EPFA migrant workers related provisions}

Another option that can be considered by the government is to review the current provisions in EPFA related to migrant workers. It is noted that the migrant worker's contribution to the fund is not made mandatory. Even if they choose to contribute, the employer is only 
obligated to contribute RM5 monthly which is much lower than the contribution made by the employer for the local workers which is based on a prescribed percentage of the employee's salary. This discrepancy demotivates the migrant workers from saving their money in the EPF scheme.

Realising the importance of having a proper retirement plan, it is proposed that the employer's share should be based on a percentage of the migrant worker's wages or at a reasonable rate to be determined by the Board. The present flat rate of RM5 which is quixotically low must be abolished. Unlike the local workers, the migrant workers are unable to enjoy payment of dividend, cannot make a nomination for the payment of credit upon the death of the worker, and are not granted gratuity payment by the EPF for death or disablement. By reviewing the current limitations vested on the migrant workers through the provisioning of the EPFA, the migrant worker should be given the option to make a nomination.

\subsection{Portability of Retirement Benefit Across Borders}

The primary measure that can be taken by the government to ensure the portability of social security rights to the migrant's home country is via bilateral and multilateral agreements which are entered with laboursending countries. These agreements may adopt the methods employed by the European Union (hereinafter referred to as EU) in terms of applying the ILO principles of coordination. A notable lesson for Malaysia as a member of the Association of Southeast Asian Nations, also known as ASEAN (hereinafter referred to as ASEAN), is also highlighted.

A closer look at bilateral and multilateral agreements reveals an insignificant number of agreements were concluded between the labour-sending and labour-receiving countries. This is caused mainly by the inadequately-developed social security systems in the laboursending countries and the lack of administrative capability to enforce such agreements. ${ }^{47}$ This problem serves as a major hindrance for the labour-sending countries to conclude the social security agreements

47 Kenichi Hirose, n.703 at 4. 
with the labour-receiving countries. ${ }^{48}$ The valuable measures adopted by the EU regarding migrant workers' rights, particularly in the field of social security, can be applied by ASEAN. ${ }^{49}$ By virtue of Article 4 of the Council Regulation 1408/71, ${ }^{50}$ the EU has mandated the European Council to provide protection for employment injury, unemployment, death, invalidity, old age, sickness, maternity, dependents, and family benefits to the migrant workers.

\subsection{Conclusion}

Similar to other countries in the modern world, Malaysia also maintains social security schemes that provide both monetary and non-monetary benefits to employees suffering from employment injury or disease. These schemes in the form of contributions by both employer and employee through an organised and structured employment injury

48 To reflect the above, United States of America which is regarded as one of the world's main countries of destination for the migrants, has so far only concluded 24 bilateral social security agreements and almost all of the agreements are entered with the fully developed nations. Conversely, Mexico which constitutes the world's second largest labour-sending country has only concluded five bilateral social security agreements so far. See "U.S. International Social Security Agreements," International Programs, Official Social Security Website, http://www.ssa.gov/international/agreements_overview.html viewed on 24 July 2015.

49 The ASEAN which consists of the countries in the Southeast region is an alliance with the aim of promoting economic and political cooperation through fostering dialogue among its ten members including Malaysia.

50 Regulation (EEC) No 1408/71 of the Council of 14 June 1971 deals with the application of social security schemes to the employed persons and their families moving within the Member States. The Regulation applies to workers including the self-employed person who are within these categories: nationals of a Member State or third country, stateless persons, refugees residing in the territory of a Member State to whom the legislation of one or several Member States applies, their family members, and their survivors. This Regulation also applies to students or those who are undergoing vocational training including the members of their families. See "Social security schemes and free movement of persons: basic regulation," Access to European Union Law, http://eurlex.europa.eu/legal-content/EN/TXT/?uri=URISERV\%3Ac10516 viewed on 29 July 2019. 
scheme are also established for the same purpose. As far as the migrant workers are concerned, their retirement savings benefits are covered in the EPFA. Despite this fact, it is worthy to note that certain impediments of the laws to the migrant workers exist, largely caused by their "migrant" status. This is because although the benefits are provided to the migrant workers, the level of benefits given is minimal compared to those enjoyed by the local employees. Further, the social security benefits covered are not transferable to their home countries because no bilateral or multilateral agreements have been made between Malaysia and the migrant workers' home countries to execute the matter. 